\title{
Newly Diagnosed Childhood Ependymoma
}

National Cancer Institute

\section{Source}

National Cancer Institute. Newly Diagnosed Childhood Ependymoma. NCI Thesaurus.

Code C115270.

A recently diagnosed ependymoma during childhood. 